\title{
PENINGKATAN KEMAMPUAN BERPIKIR KREATIF SISWA MENGGUNAKAN PERANGKAT PEMBELAJARAN BIOLOGI DENGAN PENDEKATAN TASC (THINKING ACTIVELY IN SOCIAL CONTEXT)
}

\author{
Irsad Rosidi ${ }^{1}$ \\ Muslimin Ibrahim² \\ Tjandrakirana ${ }^{3}$ \\ ${ }^{1}$ Mahasiswa Program Pascasarjana, Program Studi Pendidikan Sains, Universitas Negeri Surabaya \\ ${ }^{2}$ Professor di Jurusan Biologi, Fakultas Matematika dan Ilmu Pengetahuan Alam, Universitas Negeri Surabaya \\ e-mail:irsad.rosidi@gmail.com
}

\begin{abstract}
Research learning characterized biology with Thinking Actively in Social Context (TASC) approach to increase creative thinking skills of students has been done tested to applied in 30 students of class X SMA Negeri 1Kebomas-Gresik with one-group pretest-posttest design. The results of this research are learning performance categorized good (3.82) in the score range 1-4, the ability to think creatively students increased due to treatment (Gain Score $=0.9$ and T test $=$-tmearure $<-$ ttable $=-21.028-2.045$ ), thoroughness student learning outcomes in classical (0.93) and the individual (0.86) and thoroughness indicators (0.92) increased by the treatment (Gain score $=0.8$ ) and categories are complete, and the response students positive (98 percent). The conclusions this research, learning with TASC approach can improve the creative thinking ability of senior high school student.
\end{abstract}

Key words: Ceative Thinking Skills, Learning Resouces, TASC Approach.

\begin{abstract}
Abstrak: Telah dilakukan penelitian pembelajaran biologi dengan pendekatan Thinking Actively in Social Context (TASC) dengan tujuan meningkatkan kemampuan berpikir kreatif siswa dan diujicobakan pada 30 siswa kelas X SMA Negeri 1 Kebomas-Gresik dengan desain one group pretest-posttest. Analisis data secara deskriptif kualitatif dengan hasil pengamatan keterlaksanaan pembelajaran kategori baik (3,82) dalam rentang skor 1-4, kemampuan berpikir kreatif siswa meningkat akibat perlakuan (Gain Score $=0,9$ dan uji $T=$-thitung $<$-ttabel $=-21,028<-2,045)$, ketuntasan hasil belajar siswa secara klasikal $(0,93)$ dan individu $(0,86)$ serta ketuntasan indikator $(0,92)$ meningkat akibat perlakuan (Gain score $=0,8)$ dan kategori tuntas, serta respon siswa positif (98\%). Simpulan penelitian ini, pembelajaran dengan pendekatan TASC dapat meningkatkan kemampuan berpikir kreatif siswa SMA.
\end{abstract}

Kata Kunci: Kemampuan berpikir kreatif, perangkat pembelajaran biologi, pendekatan TASC

\section{PENDAHULUAN}

Salah satu masalah yang dihadapi oleh dunia pendidikan di negara kita adalah lemahnya proses pembelajaran (Puspita, 2010). Tukan (2010) menegaskan bahwa lemahnya proses pembelajaran di Indonesia lebih mengedepankan filosofi "vocal teacher, silent student (guru berbicara, murid diam)". Pada saat proses pembelajaran, siswa kurang didorong untuk mengembangkan kemampuan berpikir dan lebih menekankan pada hafalan (Sintur, dkk, 2011). Makna belajar sendiri merupakan suatu proses aktif merangkai pengalaman, menggunakan masalah-masalah nyata yang terdapat di lingkungannya untuk berlatih keterampilanketerampilan yang lebih spesifik (Ibrahim, 2005: 1). Agar dapat tercapainya tujuan pendidikan yaitu menjadikan siswa lebih cerdas-bukan hanya lebih berpengetahuan luas atau terampil, melainkan benar-benar lebih mampu mempelajari segala jenis informasi baru, siswa harus menggunakan kemampuan berpikirnya (Beyer, 1998 dalam Slavin, 2011: 33).

Pada proses pembelajaran, siswa harus dilatihkan kecakapan berpikir (Arnyana, 2007). Keterampilan berpikir diperlukan oleh setiap orang untuk berhasil dalam kehidupannya. Menurut implikasi dari teori Piaget menyatakan bahwa pembelajaran seharusnya dipusatkan pada proses berpikir atau proses mental, bukan sekedar pada hasilnya (Slavin, 2011). Salah satunya adalah proses berpikir kreatif, merupakan aktivitas mental untuk mengembangkan atau menemukan ide-ide asli (orisinil), estetis, konstruktif yang berhubungan langsung dengan pandangan konsep dan menekankan pada aspek berpikir intuitif dan rasional (Krulik and Rudnick, 1996).

Kreativitas merupakan salah satu kemampuan intelektual manusia yang sangat penting karena dimasukkan dalam kemampuan menyelesaikan masalah, bahkan sering disebut juga sebagai berpikir kreatif (creative thinking) (Selwanus, 2010:52). Rogers (1962) dalam Munandar (2009: 18) menekankan bahwa sumber dari kreativitas 
adalah kecenderungan untuk mengaktualisasi diri, mewujudkan potensi, dorongan untuk berkembang dan menjadi matang, kecenderungan untuk mengekspresikan dan mengaktifkan semua organisme. Kreativitas dapat diajarkan melalui beberapa pendekatan, salah satunya melalui pendekatan TASC (Thinking Actively in Social Context) (Faulkner, 2008).

TASC merupakan salah satu jenis pendekatan pembelajaran dengan menggunakan penyelesaianmasalah secara umum dan untuk mempromosikan pengalaman belajar yang berbeda (Wallace, 2012: 22). Tahap-tahap dari TASC yaitu organize (mencari apa yang telah diketahui), identify (mengidentifikasi apa yang harus dilakukan), generate (mengeneralisasi cara yang akan digunakan), decide (menentukan ide yang terbaik untuk menyelasaikan masalah), implement (menerapkan ide yang telah diputuskan untuk menyelesaikan masalah), evaluate (mengevaluasi hasil implementasi ide), communicate (mengkomunikasikan dengan teman dan guru) dan learn from experience (mempelajari apa yang telah dilakukan). Lebih lanjut Maltby et al (1993) mengatakan bahwa TASC adalah sebuah model penyelesaian masalah dengan multi fase yang menggabungkan kemampuan kognitif dan strategi kognitif. TASC bertujuan untuk mengajarkan kepada siswa belajar berpikir secara analitik untuk menyelesaikan permasalahan sendiri dan mampu mengajarkan kepada siswa lain tentang apa yang telah dipelajari sendiri secara kontekstual. Menurut Maker and Zimmerman (2008), penekanan dari TASC yang telah digunakan siswa dalam proses penyelesaian masalah, terlepas dari struktur atau domain pengetahuan yang terlibat.

Lakey (2009) menjelaskan bahwa TASC menyediakan kerangka berpikir reflektif bukan hanya untuk mengembangkan penyelesaian masalah juga untuk keterampilan berpikir. Keterampilan berpikir yang dimaksudkan adalah ketrampilan berpikir kreatif. Lebih lanjut Faulkner (2009) menyatakan bahwa kerangka TASC disajikan sebagai sebuah alat yang dapat digunakan untuk membantu memfasilitasi berpikir kreatif. Hal ini sejalan dengan tujuan pembelajaran biologi, yaitu mata pelajaran Biologi dikembangkan melalui kemampuan berpikir analitis, induktif, dan deduktif untuk menyelesaikan masalah yang berkaitan dengan peristiwa alam sekitar.

Salah satu permasalahan yang paling dekat dengan siswa adalah permasalahan lingkungan. Permasalahan lingkungan yang paling banyak diungkapkan dalam kajian biologi adalah permasalahan pencemaran lingkungan. Pencemaran lingkungan secara umum dapat dibedakan menjadi pencemaran air, pencemaran udara, dan pencemaran tanah. Pencemaran tersebut berasal dari bahan pencemar yang ada di sekitar siswa atau yang dikenal sebagai limbah. Limbah yang ada di sekitar siswa terdapat beberapa jenis. Jenis-jenis limbah ini harus dikenal oleh siswa sehingga siswa mampu mengatasinya. Hal ini sesuai dengan kompetensi dasar biologi kelas X semester 2 pada kompetensi dasar 4.3 yaitu menganalisis jenis-jenis limbah dan daur ulang limbah. Untuk mengajarkan bagaimana siswa mampu menganalisis jenis limbah dan bagaimana mengatasinya, ini mungkin dapat di ajarkan melalui pembelajaran biologi dengan pendekatan TASC.

Pembelajaran dengan pendekatan TASC dapat meningkatkan kreativitas dalam mengatasi permasalahan limbah melalui kegiatan daur ulang. Melalui pendekatan TASC, siswa diajarkan bagaimana menganalisis dan membangun ide-ide kreatif dalam menyelesaikan masalah di sekitar siswa. Sehingga mampu mengatasi permasalahan lingkungan yang ada di sekitar siswa. Bedasarkan hal tersebut maka dilakukan penelitian tentang "Peningkatan Kemampuan Berpikir Kreatif Siswa Menggunakan Perangkat Pembelajaran Biologi dengan Pendekatan TASC (Thinking Actively in Social Context)" perangkat pembelajaran yang telah dikembangkan meliputi silabus, rencana pelaksanaan pembelajaran (RPP), lembar kegiatan siswa (LKS), bahan ajar, tes kemampuan berpikir kreatif dan tes hasil belajar, diharapkan mampu meningkatkan kemampuan berpikir kretif siswa.

\section{METODE}

1. Subjek Penelitian

Subyek penelitian ini adalah perangkat pembelajaran Biologi dengan pendekatan TASC (Thinking Actively in Social Context) yang dikembangkan dan diujicobakan pada 30 siswa kelas X SMA Negeri 1 Kebomas-Gresik.

2. Rancangan Penelitian

Uji coba perangkat yang dikembangkan dalam penelitian ini menggunakan rancangan One Group Pretest-Postest Design seperti digambarkan berikut (Tuckman, 1978: 142):

\section{$01 \times 02$}

\section{Keterangan:}

$\mathrm{O} 1=$ Hasil uji awal (Pre Test)

$\mathrm{X}=$ Perlakuan yang diberikan

O2 = Hasil uji akhir (Post Test)

\section{Prosedur Penelitian}

Pada penelitian ini, dilakukan berdasarkan langkah-langkah sebagai berikut :

Persiapan. Pada tahap ini peneliti mengembangkan perangkat pembelajaran yang meliputi silabus, RPP, LKS, bahan ajar siswa, tes hasil belajar, dan tes kemampuan berpikir kreatif.

Validasi. Validasi bertujuan untuk mengetahui kevalidan perangkat pembelajaran yang telah 
dikembangkan sebelum diimplementasikan di dalam kelas. Pada tahap ini, dilakukan validasi kepada tiga pakar yang meliputi Prof. Dr. Muslimin Ibrahim, M.Pd., Prof Dr. dr. Tjandrakirana, Sp. And, M.S., dan Dr. Fida Rahmadiarti, M.Kes. Bedasarkan hasil validasi menunjukkan bahwa perangkat pembelajaran valid dengan sedikit perbaikan dan dapat diimplementasikan di dalam kelas.

Implementasi. Pada tahap implementasi dilakukan dalam tiga kali tatap muka. Sebelum dan sesudah implementasi diberikan tes baik itu tes hasil belajar dan tes kemampuan berpikir kreatif. Hasil keduanya akan dibandingkan untuk mengetahui adanya peningkatan kemampuan berpikir kreatif siswa sebelum dan sesudah diberikan pembelajaran dengan TASC. Selain itu, pada tahap ini peneliti diamati oleh dua pengamat untuk mengetahui keterlaksanaan pembelajaran di kelas dengan menggunakan perangkat yang telah dikembangkan.

\section{Teknik Pengumpulan Data}

Ada beberapa teknik pengumpulan data pada penelitian ini. Pertama yaitu dengan dokumentasi yang bertujuan untuk mendokumentasi proses belajar mengajar dengan menggunakan perangkat yang dikembangkan. Kedua dengan melakukan pengamatan. Pengamatan dilakukan dengan menggunakan lembar-lembar pengamatan, seperti lembar keterlaksanaan pembelajaran dan lembar pengamatan hambatan dalam pembelajaran. Ketiga dengan memberikan tes yang bertujuan untuk mengetahui hasil belajar siswa dan kemampuan berpikir kreatif siswa. Terakhir adalah dengan pemberian angket yang bertujuan untuk mengetahui respon siswa terhadap pembelajaran dengan menggunakan TASC.

\section{Teknik Analisis Data}

Data hasil penelitian dianalisis secara deskriptif kualitatif. Data-data tersebut meliputi, data hasil engamatan keterlaksanaan RPP yang ditentukan dengan membandingkan rata-rata penilaian yang diberikan kedua pengamat. Kedua, hasil tes kemampuan berpikir kreatif yang dianalisis dengan menghitung jumlah jawaban siswa yang relevan. Kemudian hasil tes tersebut diuji dengan uji $\mathrm{T}$ berpasangan untuk mengetahui ada tidaknya perbedaan sebelum dan sesudah diberikan perlakuan. Ketiga, hasil belajar siswa yang dihitung berdasarkan proporsi hasil belajar siswa dengan ketuntasan minimal $0,75(75 \%)$. Hasil belajar siswa juga dianalisis dengan $\mathrm{N}$ Gain Score untuk mengetahui tingkat pemahaman siswa. Terakhir adalah hasil respon siswa dan hambatan pembelajaran dianalisis bedasarkan deskriptif kualitatif.

\section{HASIL DAN PEMBAHASAN}

Bedasarkan hasil uji coba 2 perangkat pembelajaran yang telah dikembangkan dan diimplementasikan di SMA
Negeri 1 Kebomas Gresik berupa keterlaksaanaan pembelajaran, kemampuan berpikir kreatif, hasil belajar siswa, respon siswa dan hambatan selama pembelajaran, akan ditampilkan berikut ini:

\section{Pengamatan Keterlaksanaan Pembelajaran}

Pengamatan keterlaksanaan pembelajaran meliputi lima aspek, yaitu: (1) kegiatan pendahuluan yang terdiri atas kegiatan memotivasi siswa, mengingatkan dengan pembelajaran terdahulu, dan menjelaskan tujuan pembelajaran. (2) Kegiatan inti yang meliputi presentasi materi, mengorganisasikan siswa untuk belajar, membimbing siswa dalam penyelidikan dan pengamatan, mengembangkan dan mempresentasikan hasil penyelidikan, dan menganalisis dan mengevaluasi pembedahan. (3) Kegiatan penutup meliputi: memberikan rangkuman pembelajaran dan memberikan tugas. Aspek ke-4 dan ke-5 adalah pengelolaan waktu dan pengamatan suasana kelas.

Berdasarkana hasil pengamatan keterlaksanaan pembelajaran yang dilakukan oleh dua pengamat (Gambar 3.1) menyatakan bahwa seluruh tahapan pembelajaran terlaksana secara keseluruhan dengan kategori tiap aspek adalah baik pada rentang skala 3,5-4,0. Tetapi terdapat kekurangan pada pengelolaan waktu terutama pada pertemuan pertama. Kurangnya pengelolaan waktu pada pertemuan pertama ini disebabkan kurangnya pengelolaan waktu pada saat siswa melakukan kegiatan observasi di luar kelas yaitu kegiatan observasi limbah di kantin sekolah dan limbah di ruang tata usaha. Untuk pertemuan selanjutnya pengelolaan waktu berjalan baik

Reliabilitas instrumen keterlaksanaan RPP sebesar $86 \%$. Dalam hal ini bisa diasumsikan bahwa instrumen yang digunakan masih reliabel. Intrumen keterlaksanaan RPP dikatakan reliabel, apabila releabilitasnya $\geq 75 \%$ (Borich, 1994 dalam Ibrahim, 2005: 25). Hal ini menunjukkan bahwa intrumen keterlaksanaan RPP yang telah dibuat memiliki konsistensi atau keajegan dalam mengukur keterlaksanaan RPP selama pembelajaran.

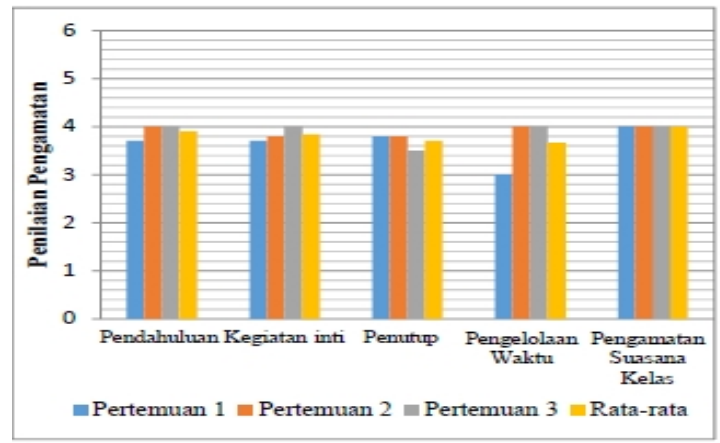

Gambar 3.1 Grafik Hasil Pengamatan Keterlaksanaan RPP.

Perancangan perangkat pembelajaran yang disusun sesuai dengan teori scaffolding dan pemagangan kognitif yang diungkapkan oleh Vygotsky. Teori scaffolding diartikan sebagai proses pemberian bantuan yang 
diberikan oleh teman atau orang dewasa (guru) yang lebih kompeten kepada siswa yang kurang berkompeten. Pada umumnya pemberian bantuan diberikan pada tahaptahap awal pembelajaran kemudian mengurangi pemberian bantuan secara bertahap, sehingga siswa mampu memecahkan masalah tanpa bantuan orang lain (self regulated) (Slavin, 2011: 59). Pemberian bimbingan diberikan kepada siswa dalam mengembangkan ide reatif dalam menyelesaikan permasalahan limbah yang ada di sekitar siswa melalui kegiatan daur ulang limbah. Ide-ide kreatif akan muncul jika diberikan bimbingan dalam bentuk pertanyaanpertanyaan yang mengarahkan siswa dalam membangun ide-ide daur ulang limbah.

Teori pemagangan kognitif didefinisika sebagai proses pemberian contoh, bimbingan, bantuan dan evaluasi diberikan selama proses pembelajaran berlangsung (Slavin, 2011: 59-60). Teori pemagangan kognitif didefinisikan pada proses dimana seseorang yang sedang belajar secara tahap demi tahap memperoleh keahlian dalam interaksinya dengan seorang pakar, pakar itu bias orang dewasa atau orang yang lebih tua atau kawan sebaya yang lebih menguasai permasalahannya. Hal ini terlihat pada saat pembelajaran, pada saat kegiatan obsevasi dilapangan maupaun pada saat kegiatan diskusi di dalam kelas. Siswa melakukan interaksi dengan teman sebayanya, guru, petugas kantin dan petugas TU sekolah dalam kegiatan observasi di luar kelas. Selain itu siswa juga melakukan diskusi dalam kegiatan penyelesaian masalah dan kegiatan pengembangan ideide kreatif dalam upaya daur ulang limbah hasil dari kegiatan observasi.

Teori pemagangan kognitif didefinisikan sebagai proses pemberian contoh, bimbingan, bantuan dan evaluasi diberikan selama proses pembelajaran berlangsung (Slavin, 2011: 59-60). Teori pemagangan kognitif didefinisikan pada proses dimana seseorang yang sedang belajar secara tahap demi tahap memperoleh keahlian dalam interaksinya dengan seorang pakar, pakar itu bias orang dewasa atau orang yang lebih tua atau kawan sebaya yang lebih menguasai permasalahannya. Hal ini terlihat pada saat pembelajaran, pada saat kegiatan obsevasi dilapangan maupaun pada saat kegiatan diskusi di dalam kelas. Siswa melakukan interaksi dengan teman sebayanya, guru, petugas kantin dan petugas TU sekolah dalam kegiatan observasi di luar kelas. Selain itu siswa juga melakukan diskusi dalam kegiatan penyelesaian masalah dan kegiatan pengembangan ideide kreatif dalam upaya daur ulang limbah hasil dari kegiatan observasi.

Pertanyaan yang dikembangkan selain untuk mengembangkan ketrampilan berpikir kreatif siswa juga digunakan untuk meningkatkan pemahaman siswa terhadap konsep limbah dan daur ulang limbah. Pada kegiatan ini juga dikembangkan teknik sumbang saran yang telah dikembangkan oleh Alex F. Osborn, pada kegiatan ini siswa dalam kelompok bebas memberikan gagasan dalam upaya daur ulang limbah dari limbah yang ditemukan siswa selama kegiatan observasi di kantin sekolah dan tata usaha. Pemberian gagasan atau ide secara bebas ini sesuai dengan tahap TASC yaitu pada tahap Generate, pada tahap ini siswa dalam kelompok bebas menuliskan gagasan atau ide kreatif siswa dalam melakukan upaya daur ulang limbah dengan menciptakan produk daur ulang limbah.

Salah satu hal yang menentukan sejauh mana seseorang itu kreatif adalah kemampuan untuk dapat membuat kombinasi baru dari hal-hal yang ada. Anak yang kreatif dapat membuat aneka ragam benda dengan menggunakan bahan-bahan bekas yang sudah tidak terpakai (Munandar, 1992: 48). Dengan kata lain, pemberian kegiatan belajar yang sudah dikembangkan tersebut mampu meningkatkan kemampuan berpikir kreatif siswa.

\section{Hasil Kemampuan Berpikir Kreatif}

Pada penelitian ini, kemampuan berpikir kreatif diukur dengan memberikan tes kemampuan berpikir kreatif yang mengadopsi pada tes verbal yang telah dikembangkan sebelumnya oleh Munandar (1992) dan Mustami (2007). Untuk mengetahui adanya peningkatan kemampuan berpikir kreatif siswa maka tes ini diberikan pada saat sebelum pembelajaran dan sesudah pembelajaran. Pada tes yang dikembangkan meliputi lima sub unit tes yang nantinya mewakili masingmasing indikator dari keterampilan berpikir kreatif yaitu kelancaran (fluency), keluwesan (flexibility), keaslian (originality) dan memerinci (elaboration). Tes verbal yang dikembangkan oleh pada penelitian ini dikaitkan dengan materi limbah dan daur ulang limbah sesuai dengan topik yang diajarkan. Pemilihan tes verbal mengacu pada teori intelektual Guilford yang menyatakan bahwa berpikir kreatif atau disebut juga berpikir divergen, yang merupakan kemampuan siswa dalam memberikan berbagai macam alternatif jawaban.

Lima sub unit tes yang digunakan antara lain unit pertama tentang permulaan kata, pada tes inidigunakan untuk mengukur kelancaran dengan kata,yaitu kemampuan menemukan kata yang memenuhi prasyarat struktural tertentu. Unit kedua tentang menyusun kata, tes ini mengukur kelancaran kata yang melibatkan kemampuan dalam reorganisasi persepsi. Unit ketiga adalah sifat-sifat yang sama, pada unit tes ini mengukur kemampuan siswa dalam kelancaran memberikan gagasan yang memenuhi prasyarat teretentu dalam waktu terbatas. Unit keempat yaitu penggunaan luar biasa, pada tes ini digunakan untuk 
mengukur kelancaran dalam berpikir, karena dalam tes ini subjek harus bias melepaskan diri dari kebiasaan melihat benda sebai alat untuk melakukan hal tertentu saja. Selain itu pada tes ini juga mengukur orisinalitas dalam berpikir. Unit kelima tentang apa akibantya ini digunakan untuk mengukur kelancaran dalam memberikan gagasan dan juga mengukur kemampuan elaborasi subjek dalam mengembangkan gagasan secara memerinci (Munandar, 2009: 68-69). Semua sub tes diberikan dalam bentuk tes verbal.

Hasil tes kemampuan berpikir kreatif ini dihitung berdasarkan jumlah jawaban siswa yang relevan (Tabel 3.1). Terjadi peningkatan yang signifikan dari jumlah jawaban relevan yang diberikan oleh siswa, ini dapat diasumsikan bahwa siswa mengalami peningkatan kemampuan berpikir kreatif akibat pembelajaran dengan menggunakan pendekatan TASC (Thinking Actively in Social Context). Hal ini menunjukkan bahwa TASC memapu membatu siswa dalam meningkatkan kemampuan berpikir kreatif.

Tabel 3.1 Hasil Kemampuan Berpikir Kreatif

\begin{tabular}{|c|c|l|l|}
\hline \multirow{2}{*}{$\begin{array}{c}\text { Indikator Berpikir } \\
\text { Kreatif }\end{array}$} & \multirow{2}{*}{ Tes } & \multicolumn{2}{|c|}{ Perlakuan } \\
\cline { 3 - 4 } & & Sebelum & Sesudah \\
\hline \multirow{2}{*}{ Fluency } & unit 1 & 11,6 & 20,0 \\
\cline { 2 - 4 } & unit 2 & 7,5 & 13,6 \\
\hline Flexibility & unit 3 & 10,6 & 19,9 \\
\hline Originality & unit 4 & 11,4 & 21,8 \\
\hline Elaboration & unit 5 & 10,6 & 19,6 \\
\hline
\end{tabular}

Kemampuan berpikir kreatif atau berpikir divergen diartikan sebagai kemampuan menemukan banyaknya jawaban terhadap suatu masalah (berdasarkan informasi yang tersedia) dengan penekanan pada kuantitas, ketepatgunaan, dan keragaman jawaban (Munandar, 1992:48). Lebih lanjut bahwa makin banyak kemungkinan jawaban yang diberikan terhadap suatu masalah, maka makin kreatiflah seseorang, tetapi jawaban yang diberikan haruslah relevan dengan permasalahan yang ada, jadi, tidak hanya semata-mata banyaknya jawaban yang dapat diberikan tetapi juga mutu dari jawaban yang diberikan tersebut harus ada relevansi jawaban dengan permasalahan yang diajukan.

Pada pemberian tes sebelum pembelajaran mendapatkan skor yang relatif rendah. Banyak hal yang menyebabkan hal ini, salah satunya pemberian tes ini diberikan pada jam tambahan pelajaran pada jam terakhir setelah jam matematika. Hal ini memungkinkan mempengaruhi kemampuan siswa dalam mengerjakan tes ini. Pada jawaban unit 2 yaitu tes menyusun kata, siswa mengalami kesulitan dalam penyususnan kata-kata dari kata yang diberikan. Hal ini dapat dilihat pada Tabel 3.1 tersebut terlihat bahwa jumlah jawaban yang relevan secara rata-rata lebih sedikit dibandingkan dengan jumlah jawaban yang relevan pada sub unit tes lain. Hal ini menunjukkan bahwa kemampuan reorganisasi persepsi siswa masih kurang. Perlu adanya peningkatan dalam pengajaran kemampuan dalam reorganisasi persepsi.

Hasil tes kemampuan berpikir kreatif diuji secara statistik dengan menggunakan Uji T berpasangan (SPSS 16.0), uji ini bertujuan untuk mengetahui adanya pengaruh pembelajaran TASC terhadap kemampuan berpikir kreatif. Selain itu, untuk mengetahui perbedaan antara sebelum dan sesudah diberikan perlakuan pada masing-masing sub unit tes dan untuk mengetahui apakah peningkatan tersebut dipengaruhi oleh adanya perlakuan yang diberikaan selama ini atau bukan.

Tabel 3.2 Hasil Uji t Berpasangan

\begin{tabular}{|c|c|c|c|c|c|}
\hline & Perlakuan & Mean & $\mathrm{Sd}$. & $t_{\text {hitung }}$ & $\mathrm{t}_{\text {tabel }}$ \\
\hline \multirow{2}{*}{$\begin{array}{c}\text { Unit } \\
1\end{array}$} & Pretest & 11,60 & 4,165 & \multirow{2}{*}{$-8,720$} & \multirow{2}{*}{$-2,045$} \\
\hline & Posttest & 19,97 & 4,498 & & \\
\hline \multirow{2}{*}{$\begin{array}{c}\text { Unit } \\
2\end{array}$} & Pretest & 7,46 & 4,191 & \multirow{2}{*}{$-5,677$} & \multirow{2}{*}{$-2,045$} \\
\hline & Posttest & 13,60 & 5,751 & & \\
\hline \multirow{2}{*}{$\begin{array}{c}\text { Unit } \\
3\end{array}$} & Pretest & 10,60 & 3,756 & \multirow{2}{*}{$-11,818$} & \multirow{2}{*}{$-2,045$} \\
\hline & Posttest & 19,93 & 4,242 & & \\
\hline \multirow{2}{*}{$\begin{array}{c}\text { Unit } \\
4\end{array}$} & Pretest & 11,43 & 2,500 & \multirow{2}{*}{$-13,231$} & \multirow{2}{*}{$-2,045$} \\
\hline & Posttest & 21,76 & 3,682 & & \\
\hline \multirow{2}{*}{$\begin{array}{c}\text { Unit } \\
5\end{array}$} & Pretest & 10,60 & 2,749 & \multirow{2}{*}{$-14,149$} & \multirow{2}{*}{$-2,045$} \\
\hline & Posttest & 19,60 & 3,820 & & \\
\hline
\end{tabular}

Bedasarkan hasil uji T berpasangan didapatkan hasil (Tabel 3.2) menunjukkan bahwa nilai -thitung < -ttabel. Berdasarkan hasil tersebut dapat dikatakan bahwa nilai thitung < -ttabel, dengan demikian dapat dikatakan bahwa H0 ditolak dan H1 diterima. Hal ini menunjukkan adanya perbedaan hasil tes kemampuan berpikir kreatif sebelum dan sesudah pembelajaran dengan pendekatan TASC. Bedasarkan signifikansi juga menunjukkan bahwa hasil perhitungan menunjukan signifikansi lebih rendah $(0,00<$ 0,05). Terdapat perbedaan antara hasil tes sebelum diberikan perlakuan dengan hasil tes sesudah diberikan perlakuan. Perbedaan tersebut menunjukkan adanya peningkatan kemampuan berpikir kreatif siswa dengan $\mathrm{N}$ Gain Score $=0,9$, dengan kata lain dapat dikatakan bahwa pemberian perlakuan yaitu pembelajaran dengan pendekatan TASC mampu meningkatkan kemampuan berpikir kreatif siswa.

\section{Hasil Belajar SIswa}

Ketetapan Kriteria Ketuntasan Minimal (KKM) untuk mata pelajjaran Biologi di SMA Negeri 1 KebomasGresik adalah $\geq 0,75$. Jadi siswa dianggap tuntas jika proporsi hasil belajarnya mencapai 0,75 .

Tes yang diberikan untuk mengukur hasil belajar siswa ini merupakan tes tertulis dalam bentuk uraian. Tes ini melibatkan kemampuan berpikir siswa yang melibatkan kemampuan C1-C6 berdasarkan taksonomi Blooms yang telah direvisi, kemampuan kognitif C6 disini adalah 
kemampuan berpikir kreatif.

Merujuk pada Gambar 3.2, menunjukkan adanya peningkatan kemampuan kognitif siswa ini terlihat dari proporsi dari pre-test dan post-test.

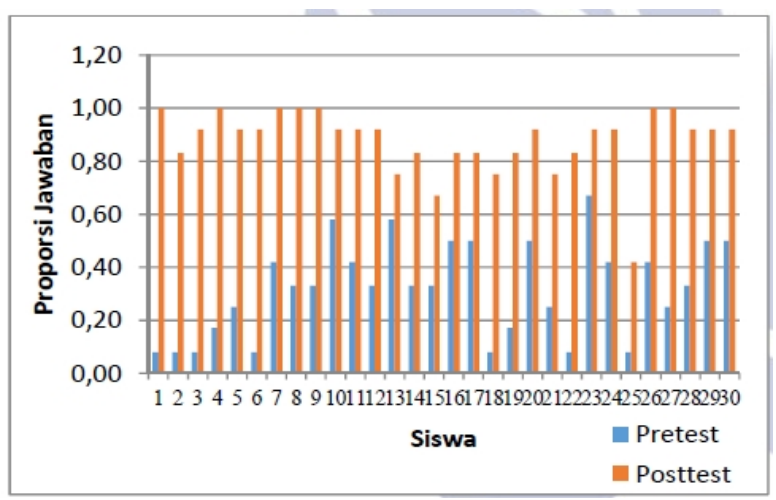

Gambar 3.2 Grafik Hasil Belajar Siswa

Peningkatan ini merupakan pengaruh dari pembelajaran yang diberikan. Hal ini sesuai dengan pengukuran indeks sensitivitas tiap butir soal yang menunjukkan bahwa indeks sensitivitas pada soal yang dikembangkan secara rata-rata 0,3 . Ini menunjukkan bahwa butir soal tersebut memiliki kepekaan yang cukup terhadap efek pembelajaran yang diberikan. Hal ini menunjukkan bahwa peningkatan hasil belajar siswa setelah diberikan perlakuan merupakan efek dari perlakuan (pembelajaran dengan pendekatan TASC) yang diberikan.

Pada post-test terjadi peningkatan proposi jawaban dari subjek. Dari 30 subjek, hamper seluruhnya mencapai KKM Biologi, hanya ada satu subjek yang belum melampai KKM yaitu subjek nomor 15 dan 25 dengan proporsi 0,67 dan 0,42 . Secara klasikal maka dikatakan kelas yang diajarkan dengan perangkat yang dikembangkan tuntas karena melampaui KKM yaitu 0,93. Sedangkan untuk ketuntasan indikator yaitu 0,92 , sehingga kelas tersebut dapat dikatakan bahwa tuntas secara klasikal dan indikator. Sehingga dapat dikatakan bahwa TASC juga mampu meningkatkan ketuntasan belajar siswa baik ketuntasan individual, indikator maupun secara klasikal. Untuk mengetahui bahwa jawaban yang mereka berikan merupan bentuk penguasaan konsep dari siswa, maka hasil tes belajar ini juga dianalisis dengan menggunakan Gain Score yan $\mathrm{g}$ ternomalisasi (N-Gain). Bedasarkan hasil N-Gain pada menunjukkan bahwa hampir seluruh siswa memiliki skor gain yang tinggi yaitu $\geq$ 0,7 , ini berarti kemampuan penguasaan konsep yang diberikan melalui pembelajaran dengan pendekatan TASC tinggi. Terdapat satu siswa yang mmendapatkan skor gain sedang yaitu siswa nomer urut 25 dengan skor gain $=0,4$, menunjukkan penguasaan konsep yang sedang biarpun telah diberikan perlakuan. Hal ini menjadi tugas guru untuk melakukan kegiatan remediasi supaya siswa dengan penguasaan konsep sedang dapat meningkat menjadi penguasaan konsep yang tinggi. Selain untuk mengetahui penguasaan konsep siswa, analisis N-Gain ini juga dapat menunjukkan adanya perbedaan antara sesudah dan sebelum diberikan perlakuan.

\section{Respon Siswa}

Untuk mengetahui seberapa besar minat siswa terhadap perangkat pembelajaran biologi dengan pendekatan TASC yang telah dikembangkan, maka dibuat angket respon siswa. Respon yang diberikan oleh siswa terhadap pembelajaran dengan menggunakan TASC menunjukkan respon yang positif. Hal ini dapat dikatakan bahwa siswa menyenangi kegiatan embelajaran dengan pendekatan TASC. Selain itu, Pembelajaran dengan TASC ini menurut siswa dapat meningkatkan kemampuan berpikir kreatif siswa. Karena pertanyaan-pertanyaan dalam kegiatan belajar siswa membangun siswa untuk aktif mengeksplorasi kemampuan berpikir siswa. Respon siswa ini meliputi dari segi materi maupun dari segi pembelajaran TASC. Ini menunjukkan bahwa pembelajaran dengan pendekatan TASC mampu meningkatkan kemampuan berpikir kreatif bukan hanya terlihat dari hasil tes kemampuan berpikir kreatif, tetapi juga terlihat dari respon siswa. Didasarkan dari respon siswa tersebut dapat dikatakan bahwa perangkat pembelajaran dan kegiatan pembelajaran dengan pendekatan TASC mampu meningkatkan kemampuan bepikir kreatif siswa.

\section{Hambatan Selama Pembelajaran}

Hambatan yang ditemukan selama proses pembelajaaran yang paling dominan adalah dalam hal pengelolaan waktu. Hal ini merupakan akibat dari belum terbiasanya siswa dalam kegiatan observasi dan pengamatan. Pembelajaran dengan melakukan kegiatan observasi dan pengamatan di luar kelas jarang dialami oleh siswa. Selain itu, pembelajaran dengan pendekatan TASC ini merupakan hal yang baru bagi siswa sehingga perlu penyesuaian untuk siswa memahami petunjuk kerja yang ada pada lembar kegiatan siswa yang ada. Solusinya adalah guru harus dapat mengefesienkan waktu yang ada dengan banyak memonitoring kegiatan siswa terutama pada saat berada di luar kelas. Guru harus terus engingatkan kepada siswa untuk berbagi tugas dan bekerja sama dalam kelompok sehingga waktu dapat diefesiensikan.

Selain itu, kurang terbiasanya siswa dalam mengembangkan gagasan/ selama prosespembelajaran. Hal ini menghambat siswa dalam pengembangan ide-ide kreatif siswa dalam menyelesaikan masalah. Solusi yang diberikan guru adalah guru memberikan bimbingan langsung kepada siswa dan memberikan contoh-contoh 
kepada siswa sehingga siswa mampu mengembangkan sendiri ide-ide mereka. Hal ini sejalan dengan teori Vigotsky yang menyatakan bahwa pemberian bimbingan harus disegerakan. Pemberian bimbingan dilakukan selama pembelajaran dengan mengurangi intensitas pemberian bimbingan agar siswa dapat mengambil perannya untuk mengembangkan ide-ide mereka.

\section{SIMPULAN}

Bedasarkan paparan di atas, maka dapat disimpulkan bahwa pembelajaran biologi dengan pendekatan Thinking Actively in Social Context (TASC) dapat meningkatkan kemampuan berpikir kreatif siswa SMA kelas X pada materi Limbah dan Daur ulang limbah. Pembelajaran dengan pendekatan TASC digunakan sebagai alternative mengembangkan kemampuan berpikir kreatif dengan memperhatikan pemilihan materi dan pembimbingan.

\section{REFERENSI}

Aiken, L.1997. Psychological Testing and Assessment, Ninth Edition. New York:McGraw .Hill Company.

Arnyana, I. B. P. 2007. "Pengembangan Peta Pikiran Untuk Peningkatan Kecakapan Berpikir Kreatif Siswa". Jurnal Pendidikan dan Pengajaran Undhiksha, No. 3 tahun XXXX/ Juli/ 2007.

Bustari dan Witjaksono. 2006. Penilaian Projek. Jakarta: Pusat Penilaian Balitbang.

Depdiknas BNSP. 2006. Panduan Penyusunan Kurikulum Tingkat Satuan Pendidikan Jenjang Pendidikan Dasar dan Menengah. Jakarta:Badan Standar Nasional Pendidikan.

Borich, G.D. 1994. Observative Skill for Effective Teaching. New York: Mc Millan Publishing Company.

Craft, A. 2005. Creativity in School: Tensions and Dilemmas.

New York: Routledge Davies, H. M. 2008. "An Overview of an Investigation into The Effect of Using TASC Strategies in The Development of Childern "s Thinking and Problem Solving Skills in Science". Gifted education International. Vol 24. pp 305.

Evans, D. 1997. "Book Review: TASC: Thinking Actively in a Social Context". Gifted Education International. Vol 12. pp 51.

Faulkner, C. 2008. "Creativity and Thinking Skills in Mathematics: Using The TASC Wheel as The Basis For Talented Puupils to Create Their Own Thinking Frameworks" Gifted Education International. Vol 24. Pp 288-296.

Gagne, R. M. 1980. "Learnable Aspects of Human Thinking. In: Lawson, A. E. (Ed)". Science Education Information Report (page 1-28). New York: The Eric
Science, Mathematics and Environmental Education Clearing House.

Gronlund, N. E. 1985. Constructing Achievement Test. $5^{\text {th }}$ Edition. New York: Prentice Hall, Inc.

Hake, R. R. 1998. Analyzyng Change/Gain Scores. USA: Indiana University.

Ibrahim, M. 2002. Pelatihan Terintegrasi Berbasis Kompetensi. Jakarta: Depdiknas.

Ibrahim, M. 2005a. Asesmen Berkelanjutan: Konsep Dasar, Tahapan Pengembangan dan Contoh. Surabaya: Unesa University Press.

Ibrahim, M. 2005b. Pembelajaran Berdasarkan Masalah. Surabaya: Unesa University Press.

Johnson, E. B. 2002. Contextual Teaching and Learning. Califorenia: Corwin Press, Inc.

Karli, H. 2003. Head-Hand-Heart (3H) Dalam Kurikulum Berbasis Kompetensi. Bandung: Bina Media Informasi.

Krulik, S. and Rudnik, J. A. 1996. The New Source Book Teaching Reasoning and Problem Solving in Junior and Senior High School. Massachusets: Allyn \& Bacon.

Lakey, J. 2009. "Purposful, Creative Problem Solving". Gifted Education International, Vol 25, pp 60-70. Maker, C. J. and Zimmerman, R. 2008. "Problem Solving in a Complex World: Integrating DISCOVER. TASC and PBL in a Teacher Education Project". Gifted Education International, Vol 24, pp 160-178.

Maltby, F. 1993. "Teaching Mathematics Through „Thinking Actively in Social Context”. Gifted Education International 1993 Vol 9, pp 45-47

Mayer, R. E. 1983. Thinking, Problem Solving, Cognition. New York: W. H. Freeman and Company.

Munandar, U. 1992. Mengembangkan Bakat dan Kreativitas Anak Sekolah. Jakarta: PT Grasindo.

Munandar, U. 2004. Pengembangan Kreativitas Anak Berbakat. Jakarta: Rineka Cipta.

Munandar, U. 2009. Pengembangan Kreativitas Anak Berbakat. Jakarta: Rineka Cipta.

Mustami, M. K. 2007. Pengaruh Model Pembelajaran Synectics yang Dipadu Mind Map dan Kooperatif STAD terhadap Kemampuan Berpikir reatif, Sikap Kreatif dan Penguasaan Materi Biologi Siswa SMP Kota Makasar. Disertasi Pendidikan Biologi. Program Pascasarjana Universitas Negeri Malang.

Nair, S. and Ngang, T. K. 2012. "Exploring Parents "e and Teachers ${ }^{\text {ee }}$ Views of Primary Pupils ${ }^{\text {ee }}$ Thinking Skills and Problem Solving Skills". Creative Education. Vol 3, No. 1, 30-36

Nur, M. 1998. Pengajaran Berpusat Kepada Siswa dan Pendekatan Konstruktivis dalam Pengajaran. 
Surabaya: IKIP Surabaya Nurhayati, N. 2013. Pencemaran Lingkungan. Bandung: Yrama Widya.

Ormord, J. E. 2008. Psikologi Pendidikan Edisi Keenam Jilid 1. Jakarta. Erlangga.

Ormord, J. E. 2009. Psikologi Pendidikan Edisi Keenam Jilid 2. Jakarta. Erlangga.

Priyatno, D. 2012. Cara Kilat Belajar Analisis Data dengan SPSS 20.0. Yogyakarta: Penerbit Andhi.

Purwanto. 2008. "Kreativitas Berpikir Menurut Guilford". Jurnal Pendidikan dan Kebudayaan, No. 074 Tahun Ke-14, September 2008.

Puspita. 2010. Paradigma Mutu Pendidikan Indonesia. Artikel bebas dipublikasikan dalam http://puspita.student.umm.ac.id/2010/08/05/paradigm -mutu- pendidikan- indonesia/ diakses tanggal 15 Oktober 2012.

Ramirez, R. P. B. and Ganaden, M. S. 2008. "Creative Activities and Students" High Oder Thinking". Education Quartetly, Vol 66 (1), pp 22-23.

Riduwan. 2013. Dasar-dasar Statistika. Bandung: Alfabeta.

Sastrawijaya, T. 2009. Pencemaran Lingkungan. Jakarta: Rineka Cipta.

Selwanus, R. A. 2010. "Pembelajaran IPS dengan Metode Problem Solving Untuk Meningkatkan Kemampuan Berfikir Kreatif Siswa di SD Negeri Naikoten Satu Kota Kupang”. Tesis Pendidikan Dasar, Program Pascasarjana Universitas Negeri Surabaya.

Sintur, M., Ramadhan A., dan Djirimu, M. 2011. "Penerapan Model Pembelajaran Masalah dan Keterampilan Berfikir Kreatif Terhadap Penguasaan Konsep Siswa tentang Biologi Kelas X SMAN 1 Dolo Selatan”. Jurnal Biodikdatis. Volume 5, Nomor 1, Desember 2011. Pp 54-63

Slavin, Robert E. 2011. Psikologi Pendidikan Teori dan Praktik Edisi Sembilan. Jakarta: PT Indeks.

Soenarno, S. M. 2011. Pengelolahan Limbah. Makalah isajikan dalam Pelatihan Pendidikan Konservasi Alam, Angkatan 26. Diselenggarakan oleh The Indonesian Wildlife Conservation Foundation (IWF) dan Balai Taman Nasional Alas Purwo. Banyuwangi, Jawa Timur, 18-19 Juli 2011.

Subekti, H. 2008. "Pengembangan Perangkat Pembelajaran Sains SMP dengan Pendekatan Science, Environtment, Thechnology and Society (SETS) pada Materi Bioteknologi”. Tesis Pendidikan Sains, Program Pascasarjana Universitas Negeri Surabaya.

Sugiharto. 1987. Dasar-Dasar Pengolahan Air Limbah. Jakarta: UI-Press Thiagarajaan, S., Semmel. D.S., \& Semmel, M.I. 1974. Instructional Development for Training Teacher of Exceptional Children a Sourcebook. Bloomington: Center for Innovation on teaching the Handicapped.

Torrace, E. P., 1962. Guiding Creative Talent. New York: Robert E. Krieger Publishing CO, Inc.

Tuckman, B.W. 1978. Conducting Educational Research. Second Edition. New York: Harcourt Brace Jovanovich.

Tukan, Daniel Dike. 2010. "Peningkatan Kemampuan Berpikir Kritis Siswa dengan Model TASC (Thinking Actively in a Social Context) pada Pembelajaran IPS". Jurnal Ilmiah VOX Edukasi Vol. 1 No. 1 Maret 2010.

Wallace, B. and Adams, H. 1993. "The Thinking Actively in a Social Context (TASC) Project: Developing The Potential ofChildren in Disadvantaged Communities". Oxford: AB Academic Publishers.

Wallace, B. 2000. "Teaching Thinking and Problem Solving kills". Educating Able. Autum 2000. Wallace, B. 2012. "Thinking in Context". Gifted Education International. Vol 28, pp 22-28.

Wallace, B., Bernardelli, A., Molyneux, C. and Farrell, C. 2012. "TASC: Thinking Actively in a Social Context. A Universal Problem Solving Process: A Powerful Tool to Promote Differentiated Learning Experiences". Gifted ducation international. Vol 28, pp 58-83. 